\title{
Geological Exploration of Marble Deposits in Toto Area, Nasarawa State, Nigeria
}

\author{
Ali Moumouni', Nathaniel Goeter Goki², Mohammed Suleiman Chaanda ${ }^{3}$ \\ ${ }^{1}$ Université Dandicko Dankoulodo de Maradi, Maradi, Niger \\ ${ }^{2}$ Nasarawa State University, Keffi, Nigeria \\ ${ }^{3}$ School of Geography, Earth and Environmental Sciences, University of Plymouth, Plymouth, UK \\ Email: alimoumouni2005@yahoo.fr
}

Received 4 January 2016; accepted 19 February 2016; published 22 February 2016

Copyright (C) 2016 by authors and Scientific Research Publishing Inc. This work is licensed under the Creative Commons Attribution International License (CC BY). http://creativecommons.org/licenses/by/4.0/ c) (i) Open Access

\begin{abstract}
Geological mapping as well as chemical analysis for marble deposit in the Muro-Obugu-Panda area of Toto Local Government, Nasarawa State, Nigeria, was carried out. The objectives of the study are to first map out the extent of the deposit and then evaluate its chemical characteristics. The geology of the area forms part of the Upper Proterozoic low-grade (green schist facies) schist belts of Central Nigeria, and consists of schists, banded iron, quartzite, and marble. Geological mapping revealed that the marble deposit stretches in a NE-SW direction, from Muro in the north to Kolo in the south, covering about $28 \mathbf{~ k m}^{2}$. This deposit consists mainly of silicified gray and white varieties of marble. The mapping also identified three (3) exploration targets $\mathrm{A}-\mathrm{Panda}, \mathrm{B}-\mathrm{Obugu}$, and $\mathrm{C}-$ Soka. Chemical analysis of eight (8) selected samples shows that $\mathrm{CaO}$ content varies from 3.72 to $53.12 \mathrm{wt} \%$. Other impurities are $\mathrm{Fe}_{2} \mathrm{O}_{3}, \mathrm{Al}_{2} \mathrm{O}_{3}, \mathrm{MgO}$ and $\mathrm{SiO}_{2}$. Plot of $\mathrm{Na}_{2} \mathrm{O}+\mathrm{K}_{2} \mathrm{O}$ vs. $\mathrm{SiO}_{2}$ shows a positive correlation while that of $\mathrm{CaO}$ and $\mathrm{MgO}$ exhibits a well defined negative correlation with $\mathrm{SiO}_{2}$ and this reflects the introduction of chert during the deposition of the parent limestone of the marble body. The variation plot of $\mathrm{CaO}$ vs. MgO shows an inverse relationship. This is reflected in the inverse relationship in the proportion of calcite to dolomite in the marble. All these results correlate with those found in the adjacent area by previous workers and this indicates the same extension of marble in these areas. The Muro marble can be used economically as raw materials for a variety of products such as fillers, glass, papers, lime, pesticide and sewage treatment, decorative construction, monuments, paint making and most of all very suitable for cement production.
\end{abstract}

\section{Keywords}

Marble, Muro, Obugu, Panda-Toto, Geochemistry 


\section{Introduction}

Toto area of Nasarawa State, Nigeria, is endowed with an extensive marble deposit associated with schist, quartzite and banded iron formation. The area covers Katakwa sheet 228 NE, SW, NW, and SE 1:50,000. It falls within longitude $7^{\circ} 11^{\prime}-7^{\circ} 18^{\prime}$ and latitude $8^{\circ} 7^{\prime}-8^{\circ} 23^{\prime}$ (Figure 1 ).

It is accessible through Gadabuke-Muro-Soka and Toto-Ugya-Kolo-Panda-Ayiwawa-Ladaya feeder roads, which have their major linkages from Keffi-Nasarawa-Gadabuke-Toto and from Abuja-Abaji-Toto highway roads. The vegetation is the savannah type with thick forest and tall grasses. There exist streams where some form the major tributaries of River Benue. Geologically, the study area belongs to the schist belt of Nigeria. The major rock types include schists, banded iron, quartzites, and marble. Of particular interest is the extensive occurrence of marble in this area where mining at Soka, Obugu, Ayiwawa, Panda and Kolo near Ugya dates many years back. The objective of this study is to produce a geological map so as to delineate the extent and disposition of the marble deposit and then also to characterize its chemical composition being the first of its kind, hence this would subsequently determine the primary and secondary end user that would require it as a form of raw material or otherwise.

\section{Materiel and Method}

In order to carry out the study, materiel such as a topographic map: Katakwa Sheet 228, NW, NE, SW and SE at 1/50,000 scale; a Global Positioning System (GARMIN 12 Model); a compass clinometer (SILVA); a geological hammer; some sample bags; a digital camera; a field note book; some writing materials were acquired for a successful conduct of the fieldwork.

The first stage of the field mapping on a scale of 1:50,000 involved traversing both across and along the strikes of the lithologic units. This was to have a full picture of the extent of the marble occurrence in the area. Coordinates, strikes and dips were recorded at each location. Samples were collected and properly labeled. The second stage involved a rigorous and systematic synthesis of all geological data which include lithologies, measured dip and strikes of foliation planes and all structural dispositions of the marble deposit and its relationship with the other rocks. The collected data consequently were plotted unto a GIS-based digitization packages, using Idrisi 32 and ArcView GIS 3.2a. The sheets covering the area were first scanned, cropped and exported in acceptable formats, and latter used to capture all the layers to build the geological map.

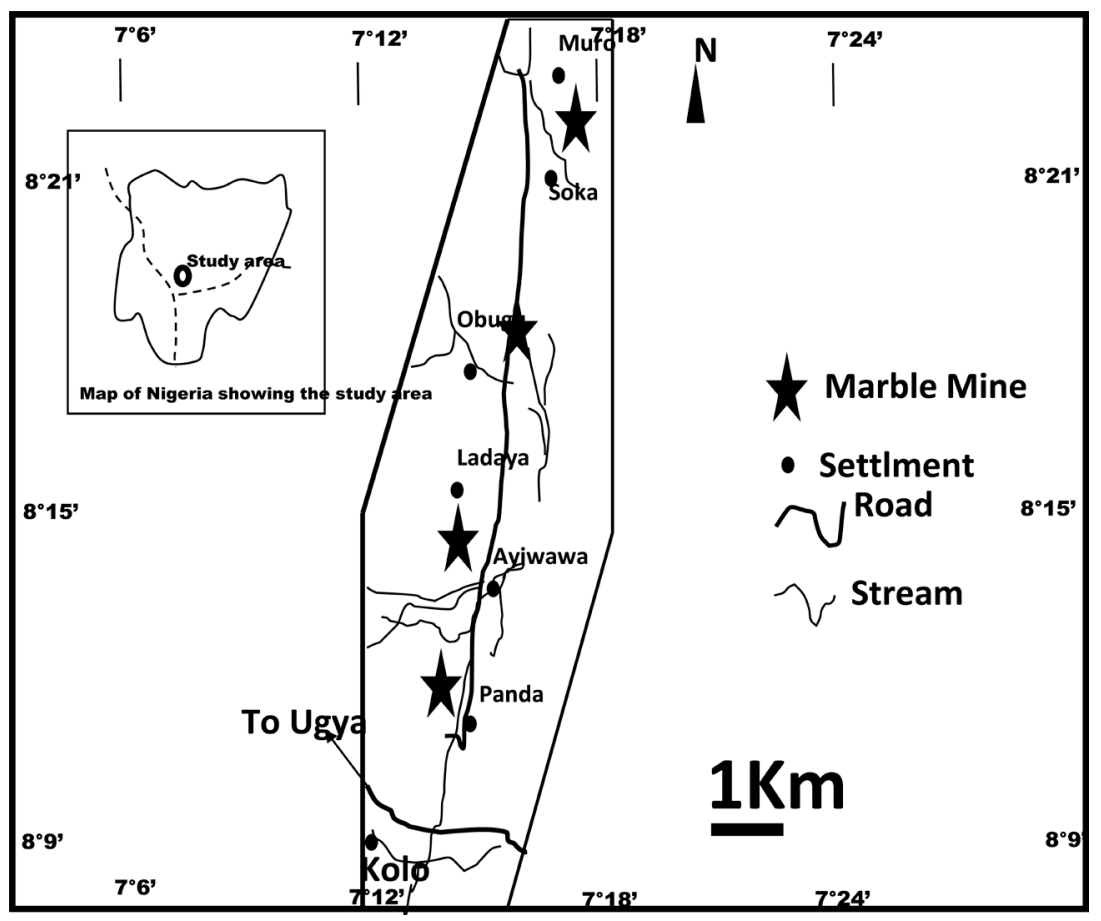

Figure 1. Location map. 
The chemical analysis of eight (8) representative marble samples was carried out at the Obajana Cement Company Laboratory, using X-Ray fluorescence Spectrometry where oxides of Calcium, magnesium, iron, sodium and. The Loss of Ignition (LOI) was also determined for the same samples. The last stage involved data interpretation and report writing.

\section{Results and Discussion}

\subsection{Geology}

Geologically, the study area belongs to the Schist Belts province, which is well developed in the western Nigeria, stretching from the northwestern, central to southwestern Nigeria [1]. The lithological variations of the schist belts include coarse to fine grained clastics, pelitics schists, phyllites, banded iron formation, carbonate rocks (marbles/dolomitic marbles) and mafic metavolcanics (amphibolites). References [2] and [3], based on structural and lithological associations; suggest that there are different ages of sediments. However, [4] disagree with this conclusion and show that both series contained identical deformational histories.

Toto area falls specifically on the Central Schist Belt of Nigeria and the geology forms part of the Upper Proterozoic low-grade (green schist facies), which consists of phyllitic schist, quartzite, marble, banded iron formation and sandstone covering the solid geology in the some parts of the area [1] [5]. The northwestern and southwestern belts are known to be associated with gold, believed to be sourced from deep-seated faults and shear zones, while the central belts, though lacking in substantial gold, are known for supracrustal rocks associated with quartzitic banded irons interlayed with metamorphic marble stretching from Jakura Marble in Kogi State currently mined for cement production, to the Muro area marble in Nasarawa State. The marble occurs associated with steeply dipping quartzites, schists, banded iron and gneisses with prominent quasi-N-S trending strike directions and steep dips.

The area investigated consists of almost north-south to NE trending metasedimentary series including phyllitic schist, quartzite, banded iron, marble and undeformed sandstones (Figure 2). The quartzites, banded irons form elongate ridges while the marble and schists appear low-lying, except in areas where the deformation and folding have upthrusted them producing near vertical to steeply dipping foliation surfaces. Most foliation surfaces measured on all the lithologies dip to the west and north-west and in some case vertical, signifying probably that the whole complex structure may be a part of an arm of an anticlinal structure as evidenced by a corresponding eastward dip in the far western flank around Yerwa on quartzite and phyllitic schists. The following lithologies were identified.

\subsubsection{Schists}

The schists occupy the low-lying area mostly, but could be found uplifted and associated with quartzites on the ridges. They consist mineralogically of quartz-mica and phyllitic varieties and in some cases carbonaceous. The mica is mostly biotite and at contact with quartzite, may be rich in muscovite. Similar schists zones in Nigeria that are studied extensively are those of Igarra area [6]-[9]. Systematic mapping could not map visible contacts between the varieties due to deformation and extensive weathering. Foliation surfaces are very visible on these rocks with a general N-S strike and westward dips.

\subsubsection{Quartzite}

Granoblastic quartzite outcrops as elongate ridges consistent with the general structural grain alignment of the area with a near N-S and N-W strike, the whitish and light colored types predominate except in cases where the iron and dark colored mica are present. Texturally, the clearly banded quartzites consist of equigranular quartz and muscovite. The main ridges outcrop north of Muro Hill traceable along strike right down to Panda area. In places they have been disjointed by post emplacement NW-SE brittle deformations possibly explaining the general dismembered outcrops of iron rich quartzites. A sedimentary origin is corroborated by these texture and fabric but in places specially at stream near Obugu, highly jointed outcrops appear to be sedimentary in origin, signifying possibly that the metamorphism could have been related to hydrothermal activity during which large quartz vein have been emplaced and subjected to post metamorphic deformative phase.

\subsubsection{Banded Iron}

The iron formation occurs as bands of iron oxides and granular quartzite mostly in the Muro Hill and traceable 


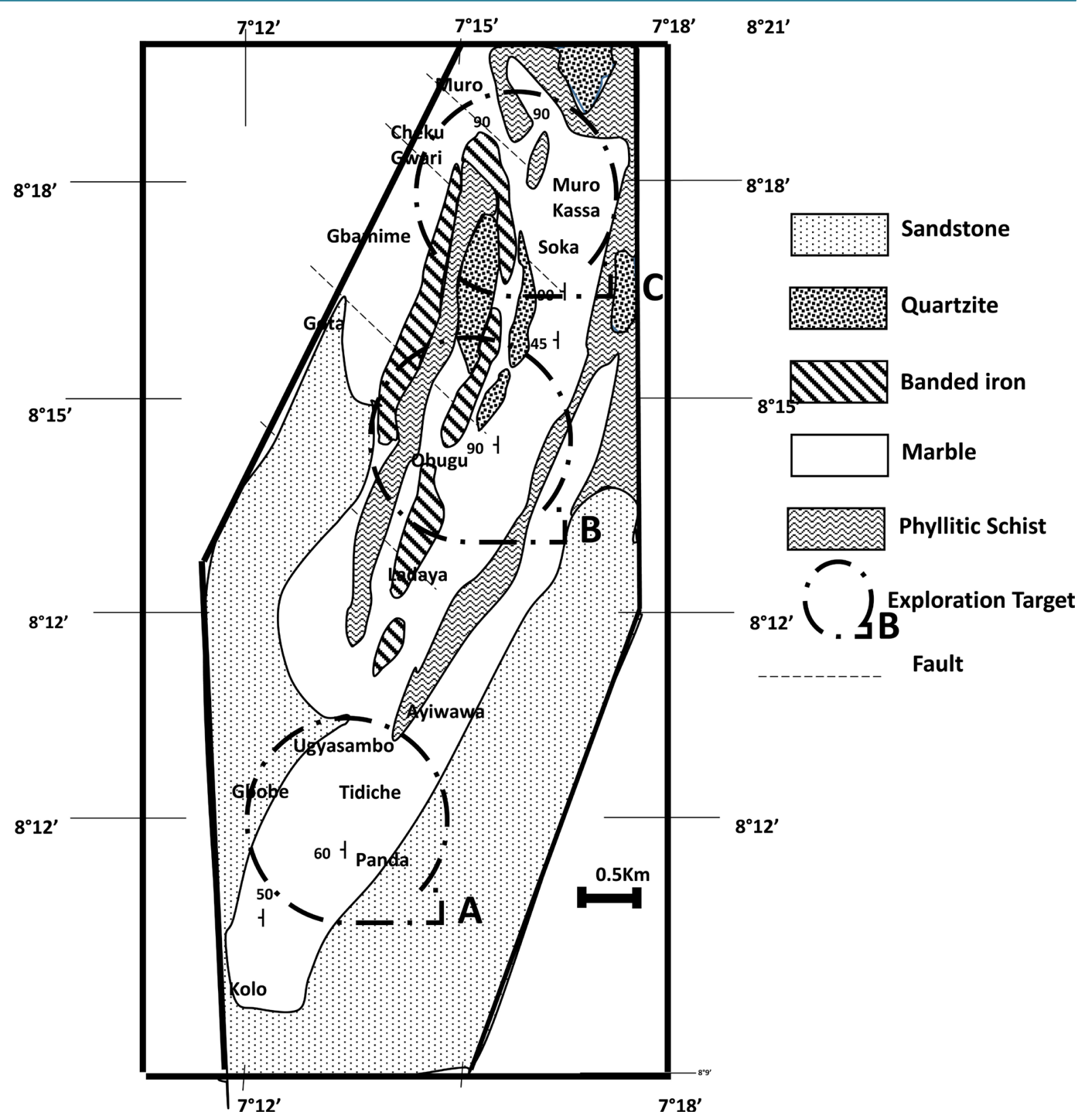

Figure 2. Geological map of the study area with exploration targets identified.

along strike to Ayiwawa area. They have been faulted and distorted as shown on the geological map (Figure 4). Banding include a few millimeters to centimeters of iron oxides (hematite) intercalated with gray to slightly yellowish quartz (including muscovite) band as a result of weathering.

\subsubsection{Sandstone}

Continental sandy sediments are overlain on the metasediments towards the south (Figure 2). The sandstones in hand specimen appear highly ferruginized in some places but further away from the ridges, they are normal brown to light coloured.

\subsubsection{Marble Deposits}

Marble deposits cover a very wide expanse with limits starting from north of Muro and Soka with an average lateral width of about 4 kilometers stretching southwards for a distance of about 7 kilometers terminating around 
Kolo in the south of the project area (Figure 2). Mapable varieties of the marble include the gray and white which evidently are the most predominant. Silicified gray types appear impure and at contact with the phyllitic rocks, visible laminae of biotite and quartz can be seen. Two main types of marble can be distinguished in the study area. These include:

\section{1) Silicified Gray Marble}

The silicified gray variety in the project area is typically banded and complexly folded. Banding ranges from a few millimeters to 10 centimeters. It is by far the widest spread and outcrop with a consistent near N-S strike. The bands alternate with the white variety, which in places could be as thick as 3 meters. Near Soka, a N-S trending gray bands marble vertically dipping 8 meters thick outcrops.

Structures include several pinch and swell structures boudinage and various types of folds including open and isoclinal folds, chevron and drag folds (Figure 3). Compositionally, the gray marbles of this area are silicified and in some places they grade into the schist.

\section{2) White Marble}

White marble outcrops as thick layers interbanded with silicified gray varieties. It is predominant around Obugu through Ayiwawa, and Panda-Ugya areas where deep mined out pits reveal sections of over 10 meters with shallow overburden thicknesses of lower than 2 meters (Figure 4). At Obugu, a very sharp contact exists between the white type eastward of about 200 meters of exposed deposit apparently less deformed and the gray type to the west about 500 meters thick complexly deformed gray with layers vertically dipping. At Panda, large deposits of the white type are exposed with a more crystalline texture. Structures are rare on the white type but the thick bands are consistently north south trending and with vertical dips.
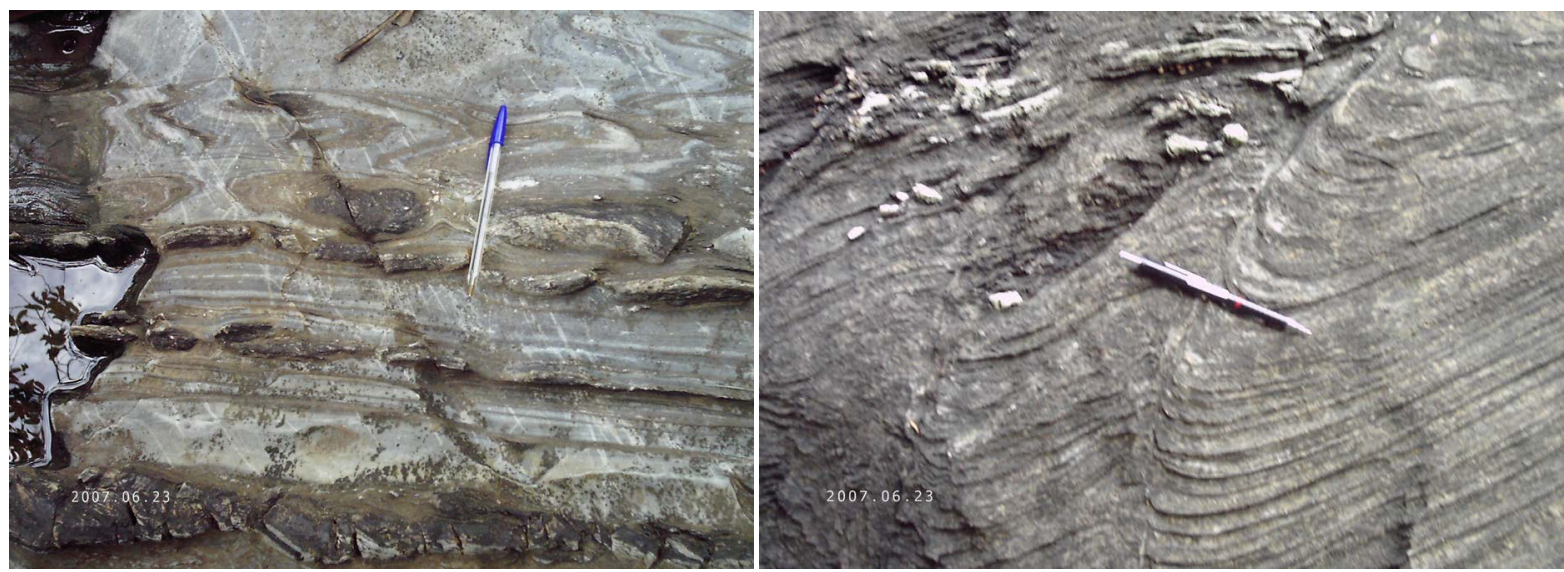

Figure 3. Pinch/swell and chevron/drag folds structures on the silicified marble in Muro.

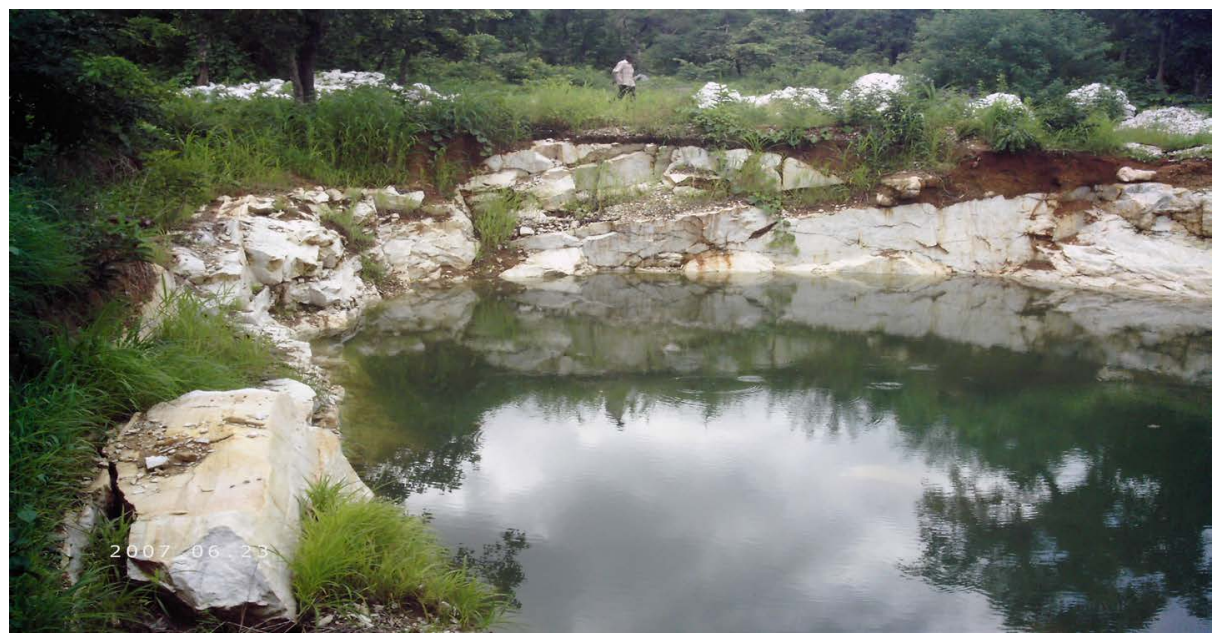

Figure 4. Mine of white marble in the study area. 


\subsection{Geochemistry}

\section{Analytical Results}

Eight samples (6 of white and 2 of dark marble) were collected and analyzed using X Ray Fluorescence Spectrometry. The results are presented in Table 1.

\subsection{Discussion}

In order to assess the quality of the Muro marble, there is need to look at the amount of $\mathrm{CaO}, \mathrm{MgO} \mathrm{Fe}_{2} \mathrm{O}_{3}, \mathrm{MgO}_{\text {, }}$ and $\mathrm{SiO}_{2}$. Iron and magnesium are admixed in the structural lattice of calcite as well as calc-silicate minerals. The theoretical composition of calcium carbonate is $56 \mathrm{wt} \% \mathrm{CaO}$ and $44 \mathrm{wt} \% \mathrm{CO}_{2}$ [10]. On the other hand [11] indicated that pure carbonates are believed to have a total carbonate content $\left(\mathrm{CaCO}_{3}\right.$ or $\mathrm{CaMg}\left(\mathrm{CO}_{3}\right)_{2}$ of $70 \%$ and above while impure carbonates have between $40 \%-70 \%$. Other oxides like $\mathrm{SiO}_{2}, \mathrm{TiO}_{2}, \mathrm{MnO}$, and $\mathrm{Na}_{2} \mathrm{O}$ are usually less than $1 \%$, and are regarded as constituting impurities \%) and our present data set has some elements of similarity with the results obtained in the Gneiss and Marble from Igarra, Southwest of Nigeria [12].

In most carbonates of metamorphic terrain, $\mathrm{CaO}$ and $\mathrm{MgO}$ are the most important elemental oxides. In calcitic type marble, $\mathrm{CaO}$ is usually in the order $50 \%-54 \%$ while $\mathrm{MgO}$ is $<15 \%$. Dolomitic or Magnesian type marble on the other hand have $\mathrm{CaO}$ values generally in the range of $28 \%-31 \%$ and $\mathrm{MgO}$ values in the range of $15 \%$ $21 \%$ [13].

Chemical analysis of the Muro marble shows $\mathrm{CaO}$ content ranging from $33.00 \mathrm{wt} \%$ to $53.12 \mathrm{wt} \%$ for the white marble and 3.72 to $5.12 \mathrm{wt} \%$ for the dark marble, meaning all $\mathrm{CaO}$ values fall below the theoretical value.

Evaluating chemical purity is important when assessing the marble's suitability for some specific uses. For example, very high chemical purity is required for filler applications. On the other hand, marble is widely used as a dimensional stone despite containing large amounts of fine grains of some sulphides (e.g. finely disseminated pyrite or marcasite). According to data of Table 1, the chemical composition of most Muro marble is not commercially suitable for uses other than a dimensional stone. The calcite content that has been calculated from the XRF analysis shows no sample has more than 97\% calcite. Therefore, the Muro marble is not suitable at its natural state for use in the paint and plastic industry. Rather it can be used as dimension stones as shown on nearby house in the study (Figure 5, Panda). Also, Muro marble when polished can used for making tiles which is subsequently used in flooring homes, offices, industries and corporate bodies to give an aesthetic look. The polished are more costly than the unpolished.

Theoretically, the LOI of pure calcium carbonate is equal to $44 \mathrm{wt} \%$ of carbon dioxide. The L.O.I. represents mainly carbon dioxide, water or other volatile components, according to the purity of the calcium carbonate. Hence, it is a very useful applicable way that is used in confirming the $\mathrm{CaO}$ content and calculating its $\mathrm{CaCO}_{3}$ content. The loss on ignition values range from 1.07 to $43.63 \mathrm{wt} \%$, which means the proportion of the impurities, is variable with the marble type. The white type marble is hence purer than the gray one. And among the white ones samples S3, S2 and S1 are the purest respectively. The internationally recommended loss on ignition

Table 1. XRF results of the Muro marble.

\begin{tabular}{|c|c|c|c|c|c|c|c|c|c|c|}
\hline \multirow{2}{*}{ S/No. } & \multirow{2}{*}{ Sample } & \multicolumn{8}{|c|}{ Chemical Parameters } & \multirow[b]{2}{*}{ LOI } \\
\hline & & $\mathrm{SiO}_{2}$ & $\mathrm{Al}_{2} \mathbf{O}_{3}$ & $\mathrm{Fe}_{2} \mathrm{O}_{3}$ & $\mathrm{CaO}$ & MgO & $\mathbf{K}_{2} \mathbf{O}$ & $\mathrm{Na}_{2} \mathrm{O}$ & $\mathbf{S}$ & \\
\hline \multicolumn{11}{|c|}{ S-Samples or white Marble } \\
\hline 1 & $\mathrm{~S} 1$ & 2.17 & 0.56 & 0.34 & 39.91 & 16.57 & 0.14 & 0.22 & 0.23 & 40.56 \\
\hline 2 & $\mathrm{~S} 2$ & 0.31 & 0.14 & 0.11 & 52.16 & 4.12 & 0.05 & 0.03 & 0.09 & 43.20 \\
\hline 3 & S3 & 0.20 & 0.02 & 0.08 & 53.12 & 3.06 & 0.02 & 0.01 & 0.03 & 43.63 \\
\hline 4 & $\mathrm{~S} 4$ & 22.69 & 4.52 & 2.23 & 33.00 & 11.09 & 0.61 & 0.98 & 0.02 & 25.80 \\
\hline 5 & S5 & 20.95 & 5.06 & 2.15 & 35.62 & 5.87 & 0.86 & 0.76 & 0.04 & 29.12 \\
\hline 6 & S6 & 12.57 & 2.91 & 0.93 & 46.13 & 4.86 & 0.49 & 0.15 & 0.20 & 31.80 \\
\hline \multicolumn{11}{|c|}{ H-Sample or silicified dark } \\
\hline 7 & $\mathrm{H} 1$ & 80.65 & 5.96 & 0.62 & 5.12 & 0.28 & 1.08 & 0.02 & 0.01 & 6.40 \\
\hline 8 & $\mathrm{H} 2$ & 88.52 & 4.65 & 1.00 & 3.72 & 0.09 & 0.74 & 0.02 & 0.19 & 1.07 \\
\hline
\end{tabular}


(LOI) value is around $40 \mathrm{wt} \%$ [14]. The white marble is the only type that fulfils the specifications for use as filler in paper and other industries.

An attempt to subject the data to a regression analysis on the geochemical data has revealed the following results: the plot of $\mathrm{Na}_{2} \mathrm{O}+\mathrm{K}_{2} \mathrm{O}$ vs. $\mathrm{SiO}_{2}$ (Figure 6) shows a positive correlation while that of $\mathrm{CaO}$ and $\mathrm{MgO}$ (Figure 7, Figure 8) exhibit a well defined negative correlation with $\mathrm{SiO}_{2}$ and this reflects the introduction of chert during the deposition of the parent limestone of the marble body. The variation plot of $\mathrm{CaO}$ vs. MgO (Figure 9) shows an inverse relationship. This is reflected in the inverse relationship in the proportion of calcite to dolomite in the marble. All these results correlate with those found on the Itobe Marble by [15] in the adjacent area. This indicates the same extension of marble in the two areas.

The protolith of the Muro marble like the Itobe marble may be a relatively pure limestone in which dolomite is present in varying proportions as found by [15]. It was most probably been deposited within shallow narrow

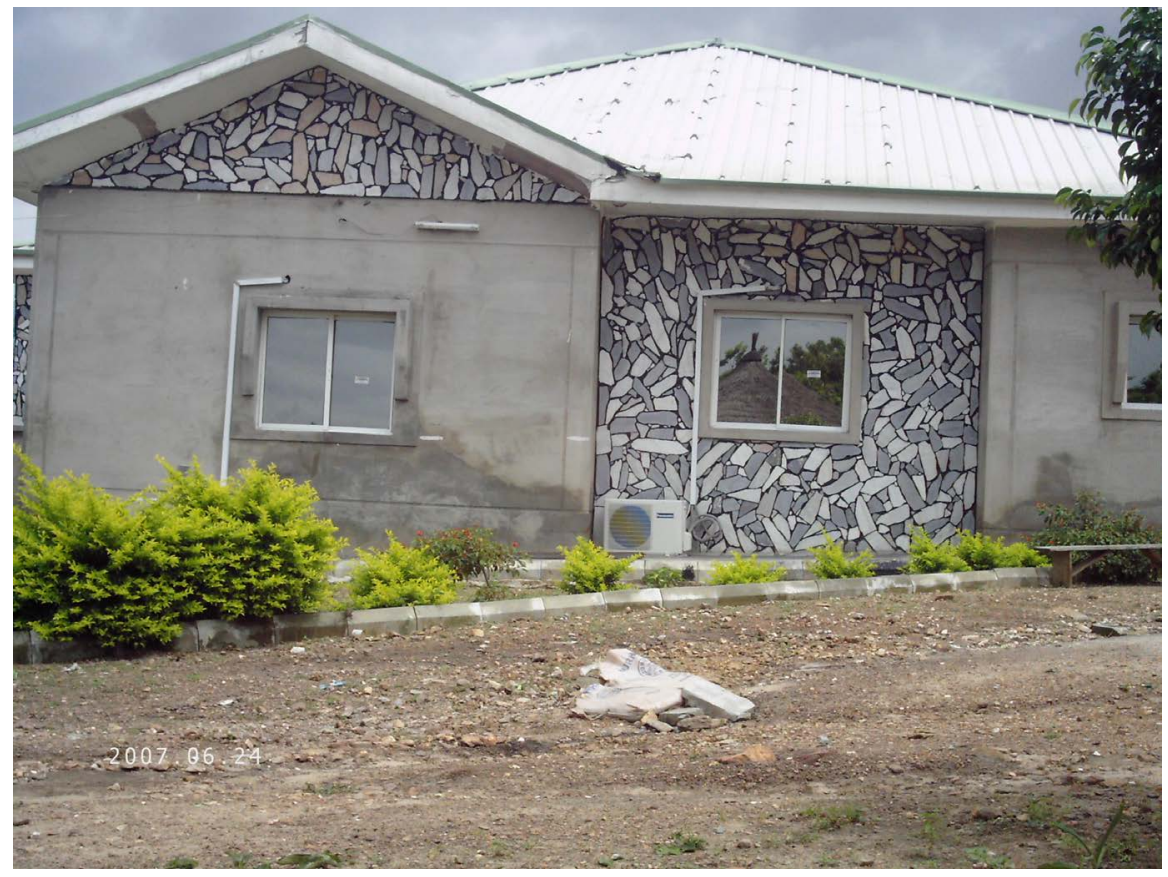

Figure 5. Use of marble for decoration at a house in the study area.

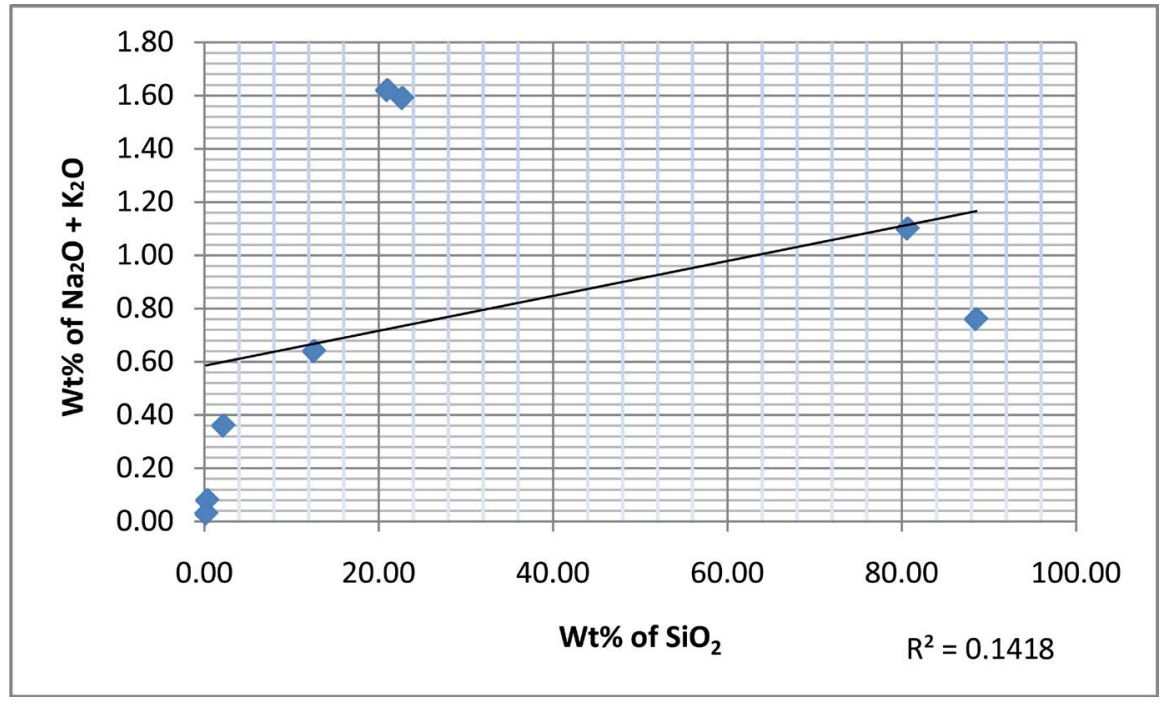

Figure 6. Plot of wt $\% \mathrm{Na}_{2} \mathrm{O}+\mathrm{K}_{2} \mathrm{O}$ vs. $\mathrm{SiO}_{2}$. 


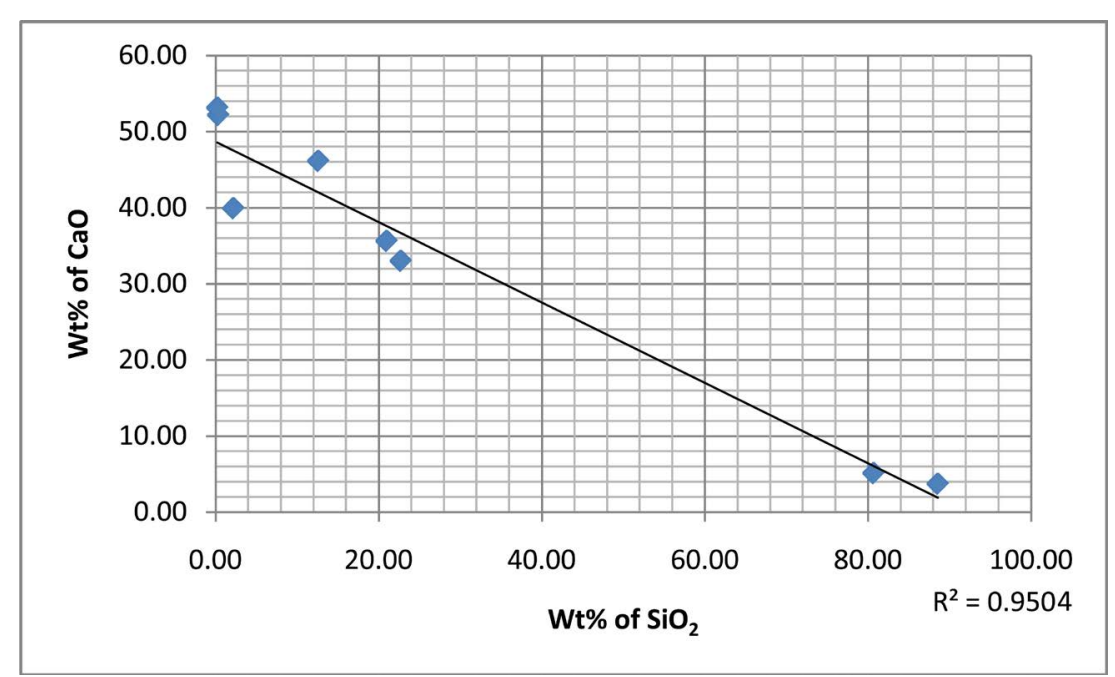

Figure 7. Plot of wt $\% \mathrm{CaO}$ vs. $\mathrm{SiO}_{2}$.

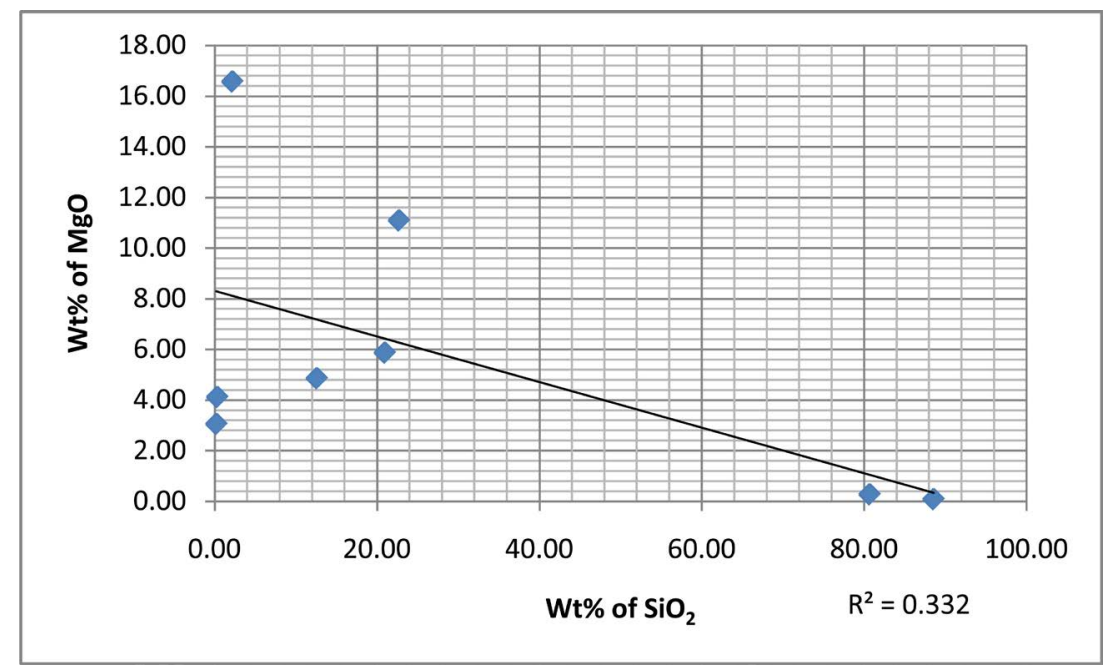

Figure 8. Plot of wt\% $\mathrm{MgO}$ vs. $\mathrm{SiO}_{2}$.

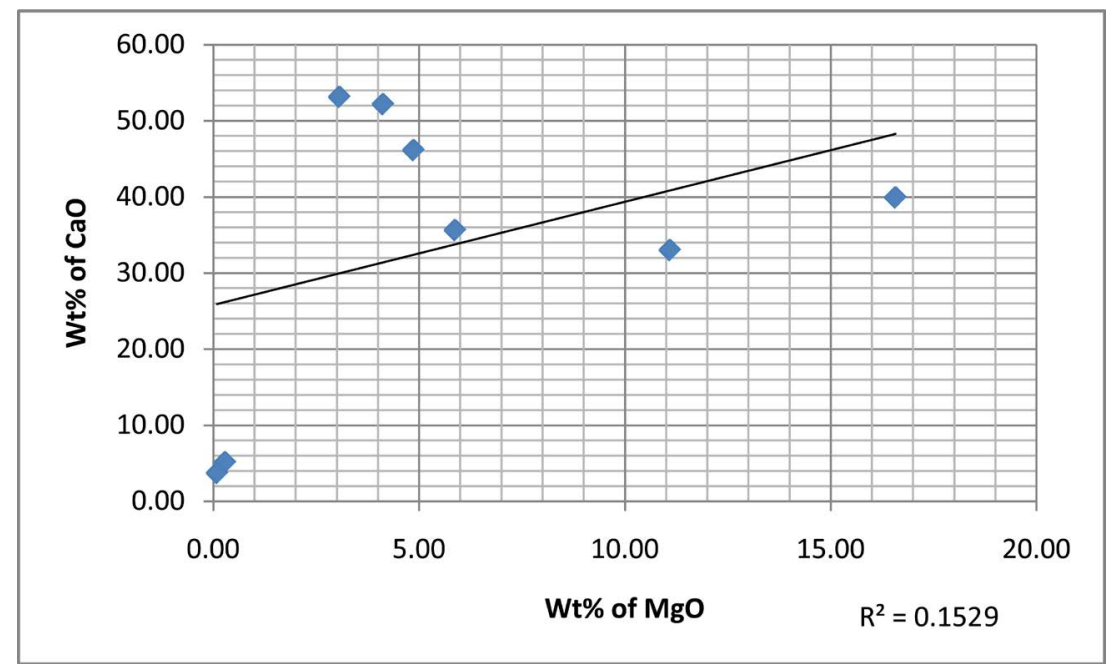

Figure 9. Plot of $\mathrm{CaO}$ vs. MgO. 
basins which were initiated in structurally controlled depressions. The associated $\mathrm{MgO}$ in the marble must have been co-precipitated with the Ca from hyper-saline waters under anoxic conditions with micro-fauna and flora playing a vital role. The Muro marble occurs in association with Precambrian basement rocks comprising biotite schist, mica schist, quartz-schist, biotite hornblende schist, feldspathic quartzite, quartzitic schist, gneissic granite and minor intrusive rocks including pegmatite and quartz veins and based on the previous studies in adjacent areas (e.g. [15]-[18] etc.) in adjacent areas we can conclude that the Muro marble of metasedimentary origin. Similarly like the marble deposits in adjacent areas, the Muro marble can be used economically as raw materials for a variety of products such as fillers, glass, papers, lime, pesticide and sewage treatment, decorative construction, monuments, paint making and most of all very suitable for cement production.

Further work on the physical properties example porosity, specific gravity, shear strength, tensile and compressive strength, hardness and bulk density of the marble should be carried out which would be used to constrain its absolute resilience and durability before selection of its industrial usage.

\section{Conclusion}

Massive marble deposits of Toto area has been investigated through mapping and chemical characterization. The mapping shows that there are three (3) exploration targets successively around Panda, Obugu, and Soka. Chemical analysis shows that the marble deposits can be used economically as raw materials for a variety of products such as fillers, glass, papers, lime, pesticide and sewage treatment, decorative construction, monuments, paint making and most of all very suitable for cement production.

\section{References}

[1] Ajibade, A.C. (1976) Provisional Classification and Correlation of Schists Belts in Northwestern Nigeria. In: Kogbe, C.A., Ed., Geology of Nigeria, Elizabethan Pub. Co., Lagos, 88-90.

[2] Grant, N.K. (1970) Geochronology of Precambrian Basement Rocks from Ibadan, South-Western Nigeria. Earth and Planetary Sciences Letter, 10, 19-38. http://dx.doi.org/10.1016/0012-821X(70)90061-0

[3] Turner, D.C. (1983) Upper Proterozoic Schist Belt in the Nigerian Sector of Pan African Province of West Africa. In: Kogbe, C.A., Ed., Geology of Nigeria, 2nd Revised Edition, Rock-view Limited, Jos, Nigeria.

[4] Ajibade, A.C., Fitches, W.R. and Wright, J.B. (1979) The Zungeru Mylonites, Nigeria: Recognition of a Major Unit. Revue de Géologie et Géographie Physique, 21, 359-363.

[5] Jones, H.A. and Hockney, R.D. (1964) The Geology of Parts of Southwestern Nigeria. Bulletin, Geological Survey of Nigeria, 31, 101.

[6] Rahman, M.A. (1992) Precambrian Geology of Nigeria. Proceedings of High Grade Terrains Benin-Nigeria Traverse, Programme and Lecture Series, 150-200.

[7] Odeyemi, I.B (1988) Lithostratigraphic and Structural Relationships of the Upper Precambrian Metasediments in Igarra Area, Western Nigeria. The Precambrian Geology of Nigeria, Geological Survey of Kaduna, 111-123.

[8] Ekweme, B.N. (1990) Petrology of Southern Obodu Plateau Bamenda Massif, Southeastern Nigeria. In: Rocci, G. and Deschamps, M.., Eds., Recent Data in African Earth Sciences, CIFEG Occasional Publication, 22, 155-158.

[9] Ekweme, B.N. (2000) Zircon Evaporation Ages from Obudu Plateau First Evidence of Archean Components in the Schist of Southeastern, Nigeria. $37^{\text {th }}$ Nigerian Mining and Geosciences Conference, Jos, Book of Abstracts.

[10] Talal, M.Q. (2000) Testing Jabal Farasan Marble Deposit for Multiple Industrial Applications. Arabian Journal for Science and Engineering, 33, 79-97.

[11] Lipmann, F. (1973) Sedimentary Carbonate Minerals. Springer Verlag, Berlin Heidelberg, New York, 229 p. http://dx.doi.org/10.1007/978-3-642-65474-9

[12] Obasi, R.A. (2012) Geochemical and Appraisal of the Economic Potential of Calc-Gneiss and Marble from Igaara, Edo State, Southwest, Nigeria. Journal of Science and Technology, 2, 1018-1021.

[13] Goldschmidth, J.R., Graff, L. and Joensu, O.I. (1955) The Occurrence of Magnesium Calcite in Nature. Geochimica et Cosmochimica Acta, 1, 212-230. http://dx.doi.org/10.1016/0016-7037(55)90033-8

[14] Boynton, R.S. (1979) Chemistry and Technology of Lime and Limestone. 2nd Edition, Wiley-Interscience, New York, 95-158.

[15] Onimisi, M., Obaje, N.G. and Daniel, A. (2013) Geochemical and Petrogenetic Characteristics of the Marble Deposit in Itobe Area, Kogi State, Central Nigeria. Advances in Applied Science Research, 4, 44-57.

[16] Okunlola, O.A. (2003) Geological and Compositional Investigation of Precambrian Marble Bodies and Associated 
Rocks in the Burum and Jakura Areas, Nigeria. Unpublished PhD Thesis, University of Ibadan, Ibadan, $250 \mathrm{p}$.

[17] Emofurieta, W.O. and Ekuajemi, V.O. (1995) Lime Products and Economic Aspects of Igbetti, Ososo and Jakura Marble Deposits in Southwest Nigeria. Journal of Mining and Geology, 31, 89-97.

[18] Elueze, A.A. and Okunlola, O.A. (2003) Compositional Features and Industrial Appraisal of the Metamorphosed Carbonate Rocks of Burum and Jakura Area, Central Nigeria. Mineral Wealth, 128, 41-54. 